\title{
Evaluation of Resistance of Cassava Half-Sib Progenies to Cassava Mosaic Disease and Their Agronomic Performances in Western Kenya
}

\author{
Eric Mpongolo Musungayi ${ }^{1,2}$, Kahiu Ngugi ${ }^{1}$, James Wanjohi Muthomi ${ }^{1}$, Vincent Woyengo Were ${ }^{3}$, \\ Florence Mmogi Olubayo ${ }^{1} \&$ Felister Mbute Nzuve ${ }^{1}$ \\ ${ }^{1}$ Department of Plant Science and Crop Protection, University of Nairobi, Nairobi, Kenya \\ ${ }^{2}$ Institut National pour l'Etude et la Recherche Agronomique, Mulungu, Congo \\ ${ }^{3}$ Kenya Agricultural and Livestock Research Organization, Kakamega, Kenya \\ Correspondence: Eric Mpongolo Musungayi, Department of Plant Science and Crop Protection, University of \\ Nairobi, Nairobi, Kenya. E-mail: musungayieric@yahoo.fr
}

Received: August 20, 2018

Accepted: September 25, $2018 \quad$ Online Published: November 15, 2018

doi:10.5539/jas.v10n12p78

URL: https://doi.org/10.5539/jas.v10n12p78

\begin{abstract}
Cassava mosaic disease (CMD) caused by Bemisia tabaci is among the major contributors to low cassava yield in Africa and therefore requires instituting control measures. Due to genetic diversity in cassava, only clones with superior agronomic traits, disease resistance and high yield are selected and released to farmers or deployed in breeding program. This study was conducted to evaluate the resistance of cassava half-sib families to CMD. Field trials were conducted at Kenya Agricultural and Livestock Research Organization (KALRO), at Kakamega and Alupe research stations in western Kenya from June 2016 to June 2017. Sixty progenies were compared to that of their five parents by planting cuttings in $4 \times 2$ meters plots. Data were collected on plant height, number of roots per plant, harvest index, root yield, dry matter content, cassava mosaic disease and whiteflies infestation. Twenty three genotypes had a mean score of 1.0 to CMD, implying that they are resistant. Cassava grown at Alupe was observed to have high number of susceptible genotypes compared to cassava grown at Kakamega, indicating the effect of the environment on the genotypes. Parental genotypes, Kaleso and MM96/4271 presented high number of progenies showing CMD resistance. Genotypes, P4G1 and P2G3 with mean root yield of $31.6 \mathrm{t}$ $\mathrm{ha}^{-1}$ and $30.0 \mathrm{t} \mathrm{ha}^{-1}$ were the highest yielding in term of root yield. A number of half-sib families generated from MM96/4271, Kaleso and MM96/0686 performed well with respect to yield recorded on their respective parents. Evaluation of new cassava varieties under local disease conditions would most likely improve the productivity of cassava through selection of resistant clones.
\end{abstract}

Keywords: cassava mosaic disease, performance, progeny, reaction, resistance, severity

\section{Introduction}

Cassava is considered as one of the most important food crop in the world. The annual production was about 276 million metric tons in 2013 (Sanginga \& Mbabu, 2015). Cassava is an important subsistence and food security crop in Africa due to the level of its tolerance to poor soils, easy propagation through stem cuttings and low rainfall (Hillocks \& Jennings, 2003). The cassava (Manihot esculenta) roots are an indispensable source of carbohydrate in several locations of the low and mid-altitude tropics. Almost, $90 \%$ of cassava produced in Africa is used for consumption which provides calories for about 500 million of people and constituting about $37 \%$ of energy requirements of the population's food (Sanginga \& Mbabu, 2015).

For a long time cassava breeding has been undertaken by the international research organizations such as the International Centre for Tropical Agriculture (CIAT) and the International Institute of Tropical Agriculture (IITA). National research stations being used only to test and disseminate developed varieties (DeVries \& Toenniessen, 2001). In this breeding approach generally referred to as conventional plant breeding approach, the breeder undertakes all breeding activities unilaterally (Virk \& Witcombe, 2007; Witcombe et al., 1996). The breeder identifies the breeding objectives, develops and test new varieties and evaluates them on research stations.

Cassava (Manihot esculenta Crantz.) production has been greatly hindered by cassava mosaic disease (CMD) in many cassava growing areas within East and Southern Africa (Pennisi, 2010). The whitefly (Bemisia tabaci), is a vector that transmits cassava mosaic disease causing viruses (Fargette \& Vie, 1995). Transmission efficiency 
differs depending on the B. tabaci biotypes and the geminivirus (Musopole, 2016). Today cassava mosaic virus is found almost in all major cassava producing areas in sub-Saharan Africa. The countries where cassava mosaic viruses, including the Ugandan variant, are found include Burundi (Bigirimana et al., 2004), Uganda (Sseruwagi et al., 2004a), Rwanda (Legg et al., 2001), Kenya (Were et al., 2004), Democratic Republic of Congo and Tanzania (Legg, 1999; Monde et al., 2010), Mozambique (Cossa, 2011), Malawi (Aloyce et al., 2013). The total crop yield losses in the world were estimated at about US \$ 1200-2400 million per annum (Thresh et al., 1997). Cassava mosaic disease was reportedly the most wide spread of the virus diseases constraining production of cassava in sub-Saharan Africa (Musopole, 2016). The distribution of cassava mosaic disease epidemic led to severe crop breakdown and losses on yield ranging from 25 to $95 \%$ which consequently affected the local farmer's income in Sub Saharan Africa (Legg et al., 2005).

Cassava yields vary with several factors such as cultivars, type of cultivars, type of soil and fertility, time of planting as well as the intensity of infestation and infection with pests and diseases respectively (IFAD \& FAO, 2000). Losses due to CMD in Africa were estimated to be up to $30 \%$ (Zhang et al., 2005).

Kawano et al. (1998) reported that in fourteen years, a total of 372,000 genotypes were developed and evaluated at International Center of Tropical Agriculture (CIAT)-Rayong, Field Crop Research Centre and three cultivars were released. Ceballos et al. (2004) attributed the low success rate in breeding for resistance to inappropriate strategies and choice of parents. Genotypes that suppress both virus replication and symptom expression in the field are always likely to be good candidates for breeding for resistance (Musopole, 2016).

In many sub-Saharan farming systems, it would be crucial to combine disease resistance with farmer preferred agronomic traits (Benesi, 2005). In Africa, the majority of cassava produced is used for consumption. Of this, $50 \%$ is used in processed form, $38 \%$ used as fresh and as boiled and $12 \%$ used for feeding animals (Bhat et al., 2012).

Therefore objective of this study was to identify high yielding half-sib progenies that are resistant to cassava mosaic disease and other traits of agronomic importance.

\section{Materials and Methods}

\subsection{Description of Study Site}

Two trials were conducted at Kenya Agricultural and Livestock Research Organization (KALRO) - Kakamega and Alupe research farms from June 2016 to June 2017. KALRO-Kakamega is in Kakamega County in western Kenya in Upper Midland. Alupe is located in Busia County in western Kenya and fall in Upper Midland or Low Midland.

\section{WESTERN \\ PROVINCE \\ Districts}

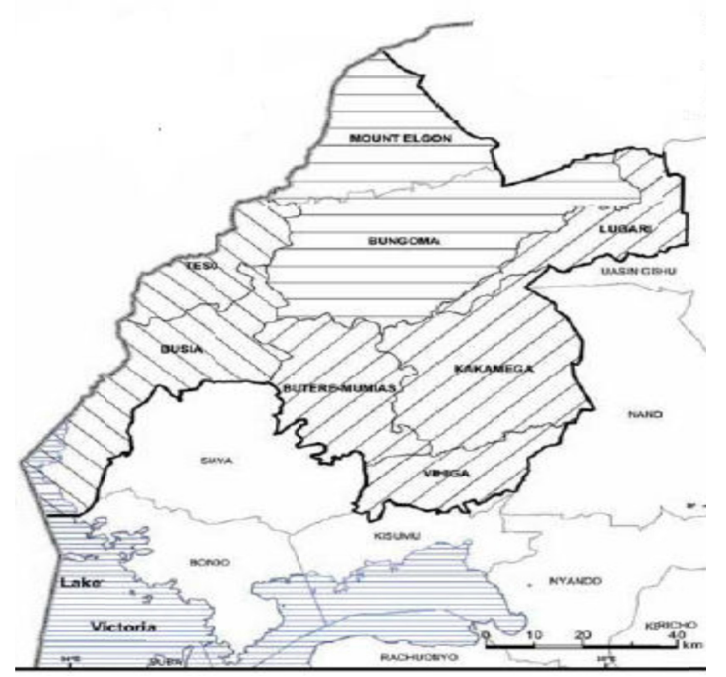

Figure 1. Map of western Kenya province 
Table 1. Characteristics of experimental sites

\begin{tabular}{|c|c|c|c|c|c|c|}
\hline \multirow{2}{*}{ Station } & \multirow{2}{*}{ Altitude (masl) } & \multirow{2}{*}{ Latitude } & \multirow{2}{*}{ Longitude } & \multicolumn{2}{|c|}{ Mean annual } & \multirow{2}{*}{ Soil type } \\
\hline & & & & Temp $\left({ }^{\circ} \mathrm{C}\right)$ & Rainfall (mm) & \\
\hline Kakamega & 1554 & $00^{\circ} 17^{\prime} \mathrm{N}$ & $34^{\circ} 47^{\prime} \mathrm{E}$ & $18.5-21.0$ & $1600-2000$ & $\begin{array}{l}\text { Well drained, deep dark red friable } \\
\text { NITOSOLS }\end{array}$ \\
\hline Alupe & 1173 & $00^{\circ} 29^{\prime} \mathrm{N}$ & $34^{\circ} 07^{\prime} \mathrm{E}$ & 21.0-22.7 & $1200-1450$ & Shallow, dark clay loam ACRISOLS \\
\hline
\end{tabular}

Source: Jaetzold and Schmidt (1983).

\subsection{Description of Cassava Germplasm}

The cassava germplasm used in the research study was obtained from Kenya Agricultural and Livestock Research Organization (KALRO) Kakamega cassava breeding program. Five parental genotypes each with 12 progenies generated through poly-cross mating design were evaluated in two locations. In order to generate families, the five parents were planted in isolated crossing block at KALRO-Alupe and allowed to randomly mate. The seeds were harvested from each parent, dried and planted in a seedbed before being transplanted into the field. Cuttings from these seedlings were used in the evaluation trial where only the seedlings that produced at least twenty quality cuttings per seedling (genotype) were included in the trial. The five elite parents, MM96/4271, MM96/0293, MM98/0686, MM96/9308 and Kaleso were selected based on their performance on cassava mosaic disease resistance, yield and yield component as these are also factors that influence the adoption of farmers.

\subsection{Experimental Design and Layout}

The experiments were conducted between June 2016 and June 2017 at KALRO-Kakamega and Alupe. Sixty half-sib clones were used in the experiment plus their five parents used as checks. Each of the sixty five genotypes was planted in a plot size of eight meter square as dimensions. Two rows plot with four plants per row per genotype were planted at a spacing of 1 meter between rows and 1 meter between plants. Eight cuttings, each with $20 \mathrm{~cm}$ of length from each genotype were used for planting in each plot. Cassava brown streak and mosaic disease spreader rows were planted using infected planting materials from highly susceptible clones called Matuja. The spreader rows were planted after every 10 genotypes to ensure high disease pressure in the trial plots. The spreader rows were planted at the same spacing as plots and maintained in a similar manner in order to strengthen the inoculation of the CMD. The experiment was laid out in a randomized completely block design. Weeding was done as required but no fertilizer and supplementary irrigation was applied.

\subsection{Data Collection}

\subsubsection{Assessment of Agronomic Parameter}

Plant height expressed in centimeters was determined by vertically measuring the plant from the ground to the top of the canopy at 12 months after planting on four middle plants in each plot.

\subsubsection{Assessment of Cassava Mosaic Disease}

Cassava mosaic disease severity was scored monthly on four middle plants in each plot using a score scale of: 1 $=$ No observable symptoms, 2 = Mild chlorotic appearance on all the young leaves or little deformation limited on their base, 3 = Strong mosaic on the whole of the sheet accompanied later narrow and deformation of the lower third of the leaflets, $4=$ Mosaic with severe deformation of the lower two thirds of leaflets and general reduction of the sports sector surface, $5=$ Mosaic with severe deformation of the leaflets on at least four fifth of their surface (Gondwe et al, 2003). Cassava mosaic disease incidence was calculated as the ratio of the number of plant with symptoms to the number of observed plants in each plot (IITA, 1990). The mean CMD damage incidence from the first month to twelve months were used to calculate, the Area Under Disease Progress Curve (AUDPC) as described by Shaner and Finney (1977) which was calculated as:

$$
\operatorname{AUDPC}=\sum_{\mathrm{i}=1}^{\mathrm{n}}\left[\left\{\frac{\mathrm{Y}_{\mathrm{i}}+\mathrm{Y}_{(\mathrm{i}+1)}}{2}\right\} \times\left(\mathrm{t}_{(\mathrm{i}+1)}-\mathrm{t}_{\mathrm{i}}\right)\right]
$$

Where, $\mathrm{n}=$ a total number of observations, $y i=$ injury intensity (usually incidence in crop health data) at the $i^{\text {th }}$ observation, $t=$ time at the $i$ th observation.

\subsubsection{Assessment of Whitefly's Nymphs}

Whiteflies' nymphs were randomly counted on nine successive leaves of different ages per plant in four middle plants in each plot, according to Abisgold and Fishpool (1990). Data were collected every fifteen days from nine to twelve months after planting. 


\subsubsection{Assessment of Yield and Yield Components}

At harvest data was collected on number of storage root per plant, harvest index, storage root yield and dry matter content. Four middle plants were harvested at twelve month after planting. The number of tubers per plant was measured as follows:

$$
\text { No. of root per plant }=\frac{\text { Number of harvested roots }}{\text { Number of harvested plants }}
$$

Harvest index was determined by harvesting four middle plants per plot and taking the weight of above ground biomass and that of the roots and calculated as follows:

$$
\mathrm{HI}=\frac{\text { Weight of roots }}{\text { Weight of roots }+ \text { Weight of above groundbiomass }}
$$

Fresh storage roots yield (FSRY) was determined by harvesting for four middle plants of each plot from each of the replications and the yield in tons per hectare $\left(\mathrm{t} \mathrm{ha}^{-1}\right)$ was calculated as:

$$
\text { FSRY }(\mathrm{t} / \mathrm{ha})=\frac{\text { Weight of roots from harvested area }}{\text { Harvested area }\left(\mathrm{m}^{2}\right)} \times 100
$$

Root dry matter content was determined using a specific gravity procedure (Okogbenin et al., 2003). Approximately $1-5 \mathrm{~kg}$ roots were weighed in the air and then submerged into water and weighed again. The formula used to determine dry matter content was:

$$
\text { Dry matter content }(\%)=\left(\frac{\mathrm{Wa}}{\mathrm{Wa}-\mathrm{Ww}_{\mathrm{w}}}\right) \times 158.3-142
$$

Where, $\mathrm{Wa}=$ Mass of roots in air and $\mathrm{Ww}=$ Mass of roots in water.

\subsubsection{Determination of Cyanide Content in Cassava Tubers}

Cyanide content was determined on four plants per clone and from three roots per plant. For each root sample, a cross-sectional cut at the mid-root position was made. The mid position was pinpointed between the peel and the center of the parenchyma and makes a $1 \mathrm{~cm}^{3}$ cube cut. The cut root cube was placed into a glass tube and five drops of toluene was added into the glass tube, then the glass tube was sealed with the stopper. A strip of Whatman filter paper was taken and dipped into freshly prepared alkaline picrate mixture until saturated. The picrate-saturated filter paper was suspended above the cut root cube in the glass tube. After twelve hours, colour change from pale green to dark brown was scored on a scale of 1 to 9 corresponding to cyanide content of between $<10 \mathrm{ppm}$ to $>150 \mathrm{ppm}$ (Fukuda et al., 2010).

\subsection{Data Analysis}

The data were analyzed statistically using the Statistical Analysis System (SAS) version 8 (SAS/STAT, 1999). Analyses of variance were done initially for each trial per site and later combined analyses of variance were conducted across the two sites. Treatment means were separated using Least Significant Difference (LSD) and declared to be significant at $95 \%$ confidence level $(\mathrm{P}=0.05)$. In addition, Pearson's phenotypic correlation between agronomic traits, cassava mosaic disease severity and incidence with yield and yield components averaged over the rating periods and sites were determined.

\section{Results}

\subsection{Plant Height}

The genotypes differed significantly $(\mathrm{P}<0.001)$ in plant heights. The height among cassava genotypes varied from $66.3 \mathrm{~cm}$ to $237.9 \mathrm{~cm}$. The half-sib progenies were taller than respective parents among parental genotypes MM97/0293, Kaleso and MM96/4271. However, progenies from family MM96/0686 and MM96/9308 were found to be shorter than their parents. Among all the progenies, parents MM96/4271 and MM96/9308 had the highest mean height of $160.0 \mathrm{~cm}$, while MM96/0686 had the lowest mean height of $126.6 \mathrm{~cm}$. The genotypes were generally tall when grown at Kakamega with mean weight of $155.6 \mathrm{~cm}$ compared to Alupe with $112.9 \mathrm{~cm}$. The tallest genotype was P5G2 from parental genotype MM96/9308 at Kakamega with height of $266.3 \mathrm{~cm}$ and the shortest was P4G5 from MM96/0686 with height of $69.6 \mathrm{~cm}$. At Alupe, the tallest genotype was P1G8 from MM96/4271 with height of $166.3 \mathrm{~cm}$ and the shortest was P5G3, from MM97/9308 with height of $52.5 \mathrm{~cm}$. Across the two sites, P5G2 was observed to be the tallest with mean height of $237.9 \mathrm{~cm}$ while P5G3 was the shortest with mean height for $66.3 \mathrm{~cm}$.

\subsection{Reaction to Cassava Mosaic Disease}

Reaction of genotypes to CMD varied significantly $(\mathrm{P}<0.001)$. Reaction of genotypes to CMD was observed to be lower at Kakamega than at Alupe. The CMD severity scores ranged from 1.0 to 4.0 in both two sites with an 
incidence ranging from 0 to $100 \%$. Considering the severity of CMD, half sib progenies from Kaleso family had the lowest mean severity of 1.5 with clone performance ranging from 1 to 3 , followed by family MM96/4271 with 1.9. Half sib progenies from family MM96/9308 had the highest mean severity among all families with a mean score of 2.7. Difference in the performance based on CMD severity between parents and their respective half sib progenies were observed. Only parental genotypes MM97/0293 showed a severity score of 1.5 among others. Though there were significant differences between parents and their respective progenies in their reaction to CMD severity, there were a varying number of symptomless clones generated from different cassava families involved. Of all the families, Kaleso had the highest percentage of clones that remained symptomless followed by MM96/4271 respectively. The lowest percentage of symptomless clones was recorded in family MM97/0293, MM96/0686 and MM96/9308.

A rapid progress in CMD incidence was observed on genotypes P2G5 generated from MM97/0293, P3G10 from Kaleso and P4G10 from MM96/0686 across sites. The three clones P2G5, P3G10 and P4G10 showed the highest score for severity followed by P5G5, P5G7, P5G9 and P5G11, all from MM96/9308 family with score 3.0 of severity.

\subsection{Population of Whitefly Nymphs}

Reaction of genotypes to whitefly nymphs number in the two sites varied significantly ( $\mathrm{P}<0.001)$. The highest number of white fly nymphs was observed on P3G8 followed by P2G7 and the lowest on P1G7 with an average number ranging from 1.4 to 40.0. Among parents, MM97/0293 showed the highest number of whitefly nymphs on the progenies followed by Kaleso. The lowest number of whitefly nymphs was observed on family MM96/0686. Most of half sib progenies showed less number of whitefly nymphs compared to the number observed on their parents. The mean number of whitefly nymphs was observed to be high at Kakamega compared to that of Alupe, respectively.

Table 2. Mean cassava mosaic disease severity score, percent incidence and whitefly's nymphs incidence on cassava genotypes evaluated at Kakamega, Alupe and across sites during 2016-2017, season

\begin{tabular}{|c|c|c|c|c|c|c|c|c|c|c|}
\hline \multirow{2}{*}{ Genotypes } & \multicolumn{3}{|c|}{ Kakamega } & \multicolumn{3}{|c|}{ Alupe } & \multicolumn{3}{|c|}{ Across sites } & \multirow{2}{*}{$\begin{array}{l}\text { Whitefly' } \\
\text { nymphs }\end{array}$} \\
\hline & $\mathrm{Sev}$ & Inc & AUDPC & $\mathrm{Sev}$ & Inc & AUDPC & $\mathrm{Sev}$ & Inc & AUDPC & \\
\hline P1G1 & 1.0 & 0.0 & 0.0 & 1.0 & 0.0 & 0.0 & 1.0 & 0.0 & 0.0 & 14.5 \\
\hline $\mathrm{P} 1 \mathrm{G} 2$ & 2.0 & 50.0 & 237.6 & 3.5 & 83.4 & 483.4 & 2.8 & 66.7 & 360.5 & 10.4 \\
\hline P1G3 & 3.5 & 87.5 & 521.9 & 3.5 & 100.0 & 853.1 & 3.5 & 93.8 & 687.5 & 8.9 \\
\hline P1G4 & 1.0 & 0.0 & 0.0 & 1.0 & 0.0 & 0.0 & 1.0 & 0.0 & 0.0 & 9.7 \\
\hline P1G5 & 1.0 & 0.0 & 100.0 & 1.5 & 50.0 & 625.0 & 1.3 & 25.0 & 362.5 & 7.4 \\
\hline P1G6 & 1.0 & 0.0 & 0.0 & 1.0 & 0.0 & 0.0 & 1.0 & 0.0 & 0.0 & 12.8 \\
\hline P1G7 & 1.0 & 0.0 & 0.0 & 1.0 & 0.0 & 0.0 & 1.0 & 0.0 & 0.0 & 1.4 \\
\hline P1G8 & 4.0 & 66.7 & 663.6 & 3.0 & 100.0 & 818.8 & 3.5 & 83.3 & 741.2 & 3.2 \\
\hline P1G9 & 3.5 & 100.0 & 705.3 & 4.0 & 100.0 & 670.7 & 3.8 & 100.0 & 688.0 & 14.2 \\
\hline P1G10 & - & - & - & 4.0 & 100.0 & 225.0 & - & - & - & - \\
\hline P1G11 & 1.0 & 0.0 & 0.0 & 1.0 & 0.0 & 375.0 & 1.0 & 0.0 & 137.5 & 8.8 \\
\hline P1G12 & 1.0 & 0.0 & 0.0 & 1.0 & 0.0 & 0.0 & 1.0 & 0.0 & 0.0 & 23.2 \\
\hline P2G1 & 3.0 & 100.0 & 500.0 & - & - & - & - & - & - & - \\
\hline $\mathrm{P} 2 \mathrm{G} 2$ & 2.0 & 37.5 & 118.8 & 3.5 & 58.4 & 362.5 & 2.8 & 47.9 & 240.6 & 11.2 \\
\hline P2G3 & 2.0 & 25.0 & 129.0 & 1.5 & 50.0 & 558.4 & 1.8 & 37.5 & 343.7 & 7.1 \\
\hline $\mathrm{P} 2 \mathrm{G} 4$ & 1.0 & 0.0 & 9.4 & 1.0 & 0.0 & 150.0 & 1.0 & 0.0 & 79.7 & 19.4 \\
\hline P2G5 & 4.0 & 100.0 & 806.2 & 4.0 & 100.0 & 890.0 & 4.0 & 100.0 & 848.1 & 24.8 \\
\hline P2G6 & 3.0 & 50.0 & 62.5 & 2.5 & 50.0 & 632.1 & 2.8 & 50.0 & 347.3 & 13.9 \\
\hline $\mathrm{P} 2 \mathrm{G} 7$ & 4.0 & 100.0 & 325.0 & 1.0 & 0.0 & 0.0 & 2.5 & 50.0 & 162.5 & 38.1 \\
\hline P2G8 & 1.0 & 0.0 & 0.0 & 2.0 & 12.5 & 118.7 & 1.5 & 6.3 & 59.4 & 12.1 \\
\hline P2G9 & 1.0 & 0.0 & 0.0 & 1.0 & 0.0 & 0.0 & 1.0 & 0.0 & 0.0 & 9.6 \\
\hline P2G10 & 1.0 & 0.0 & 0.0 & 1.0 & 0.0 & 83.2 & 1.0 & 0.0 & 41.6 & 25.8 \\
\hline P2G11 & 1.0 & 0.0 & 66.6 & 2.0 & 37.5 & 427.1 & 1.5 & 18.8 & 246.8 & 23.1 \\
\hline P3G1 & 1.0 & 0.0 & 0.0 & 1.0 & 0.0 & 300.0 & 1.0 & 0.0 & 150.0 & 3.0 \\
\hline P3G2 & 1.0 & 0.0 & 0.0 & 1.0 & 0.0 & 64.8 & 1.0 & 0.0 & 32.4 & 6.5 \\
\hline
\end{tabular}

Note. Sev = severity; Inc $=$ incidence; Whiteflies' nymphs were counted according to Abisgold and Fishpool (1990). AUDPC $=$ area under disease progress curve. 
Table 2. Contd'

\begin{tabular}{|c|c|c|c|c|c|c|c|c|c|c|}
\hline \multirow{2}{*}{ Genotypes } & \multicolumn{3}{|c|}{ Kakamega } & \multicolumn{3}{|c|}{ Alupe } & \multicolumn{3}{|c|}{ Across sites } & \multirow{2}{*}{$\begin{array}{l}\text { Whitefly' } \\
\text { nymphs }\end{array}$} \\
\hline & Sev & Inc & AUDPC & Sev & Inc & AUDPC & Sev & Inc & AUDPC & \\
\hline P3G3 & 1.0 & 0.0 & 0.0 & 1.0 & 0.0 & 33.4 & 1.0 & 0.0 & 16.7 & 2.0 \\
\hline P3G4 & 1.0 & 0.0 & 0.0 & 1.0 & 0.0 & 33.4 & 1.0 & 0.0 & 16.7 & 6.1 \\
\hline P3G5 & 1.0 & 0.0 & 0.0 & 1.0 & 0.0 & 0.0 & 1.0 & 0.0 & 0.0 & 11.9 \\
\hline P3G6 & 1.0 & 0.0 & 0.0 & 1.0 & 0.0 & 58.3 & 1.0 & 0.0 & 29.2 & 2.6 \\
\hline P3G7 & 3.0 & 83.4 & 204.1 & 3.0 & 100.0 & 500.1 & 3.0 & 91.7 & 352.1 & 25.8 \\
\hline P3G8 & 1.0 & 0.0 & 0.0 & 1.0 & 0.0 & 62.5 & 1.0 & 0.0 & 31.2 & 40.0 \\
\hline P3G9 & 1.5 & 12.5 & 156.3 & 3.0 & 50.0 & 550.0 & 2.3 & 31.3 & 353.1 & 25.9 \\
\hline P3G10 & 4.0 & 100.0 & 875.0 & - & - & - & - & - & - & - \\
\hline P3G11 & 1.0 & 0.0 & 0.0 & 1.0 & 0.0 & 0.0 & 1.0 & 0.0 & 0.0 & 14.0 \\
\hline P3G12 & 2.0 & 50.0 & 12.5 & - & - & - & - & - & - & - \\
\hline P4G1 & 1.0 & 0.0 & 0.0 & 1.0 & 0.0 & 0.0 & 1.0 & 0.0 & 0.0 & 4.8 \\
\hline P4G2 & 3.0 & 100.0 & 275.0 & - & - & - & - & - & - & - \\
\hline P4G3 & 3.0 & 37.5 & 143.7 & 3.0 & 50.0 & 212.5 & 3.0 & 43.8 & 178.1 & 16.5 \\
\hline P4G4 & 1.0 & 0.0 & 0.0 & 3.5 & 100.0 & 775.0 & 2.3 & 50.0 & 387.5 & 6.1 \\
\hline P4G5 & 1.0 & 0.0 & 0.0 & 1.0 & 0.0 & 0.0 & 1.0 & 0.0 & 0.0 & 7.4 \\
\hline P4G6 & 1.0 & 0.0 & 0.0 & 1.0 & 0.0 & 0.0 & 1.0 & 0.0 & 0.0 & 6.7 \\
\hline P4G7 & 1.0 & 0.0 & 0.0 & 2.0 & 50.0 & 225.0 & 1.5 & 25.0 & 112.5 & 2.4 \\
\hline P4G8 & 3.0 & 83.4 & 669.9 & 3.0 & 100.0 & 623.2 & 3.0 & 91.7 & 646.6 & 2.9 \\
\hline P4G9 & 3.0 & 70.9 & 347.9 & 3.0 & 83.4 & 763.6 & 3.0 & 77.1 & 555.8 & 5.6 \\
\hline P4G10 & 4.0 & 100.0 & 875.0 & - & - & - & - & - & - & - \\
\hline P4G12 & 1.5 & 33.4 & 50.0 & 3.0 & 50.0 & 525.0 & 2.3 & 41.7 & 287.5 & 3.2 \\
\hline P5G1 & 4.0 & 83.4 & 491.6 & - & - & - & - & - & - & - \\
\hline P5G2 & 3.0 & 100.0 & 704.1 & 2.0 & 25.0 & 187.5 & 2.5 & 62.5 & 445.8 & 2.9 \\
\hline P5G3 & 1.0 & 0.0 & 0.0 & 1.0 & 0.0 & 0.0 & 1.0 & 0.0 & 0.0 & 16.5 \\
\hline P5G4 & 4.0 & 100.0 & 732.1 & 3.0 & 100.0 & 806.2 & 3.5 & 100.0 & 769.2 & 3.1 \\
\hline P5G5 & 3.0 & 100.0 & 837.5 & 3.0 & 50.0 & 671.4 & 3.0 & 75.0 & 754.5 & 14.7 \\
\hline P5G6 & 3.0 & 100.0 & 475.0 & - & - & - & - & - & - & - \\
\hline P5G7 & 4.0 & 100.0 & 834.4 & - & - & - & - & - & - & - \\
\hline P5G8 & 3.0 & 100.0 & 459.4 & 3.5 & 81.3 & 718.8 & 3.3 & 90.6 & 589.1 & 7.7 \\
\hline P5G9 & 3.0 & 100.0 & 821.9 & 3.5 & 100.0 & 834.5 & 3.3 & 100.0 & 828.2 & 6.7 \\
\hline P5G10 & 1.0 & 0.0 & 0.0 & 1.0 & 0.0 & 0.0 & 1.0 & 0.0 & 0.0 & 5.3 \\
\hline P5G11 & 3.0 & 100.0 & 837.5 & 1.5 & 16.7 & 275.0 & 2.3 & 58.3 & 556.3 & 16.1 \\
\hline P5G12 & 1.0 & 0.0 & 0.0 & 1.0 & 0.0 & 0.0 & 1.0 & 0.0 & 0.0 & 9.0 \\
\hline Kaleso & 1.0 & 0.0 & 0.0 & 1.0 & 0.0 & 370.9 & 1.0 & 0.0 & 185.4 & 8.9 \\
\hline MM96/0686 & 1.0 & 0.0 & 0.0 & 2.0 & 25.0 & 16.6 & 1.5 & 12.5 & 8.3 & 13.5 \\
\hline MM96/4271 & 1.0 & 0.0 & 0.0 & 1.0 & 0.0 & 0.0 & 1.0 & 0.0 & 0.0 & 30.0 \\
\hline MM96/9308 & 1.0 & 0.0 & 0.0 & 1.0 & 0.0 & 0.0 & 1.0 & 0.0 & 0.0 & 11.3 \\
\hline MM97/0293 & 1.0 & 0.0 & 0.0 & 1.0 & 0.0 & 0.0 & 1.0 & 0.0 & 0.0 & 25.1 \\
\hline Mean & 1.9 & 32.4 & 216.9 & 1.6 & 28.0 & 327.6 & 1.8 & 30.2 & 233.9 & 12.3 \\
\hline $\operatorname{LSD}(0.05)$ & 0.8 & 32.1 & 295.6 & 1.1 & 41.3 & 386.1 & 0.75 & 39.9 & 235.0 & 12.4 \\
\hline CV (\%) & 20.9 & 44.7 & 68.21 & 32.7 & 68.7 & 58.7 & 29.6 & 66.5 & 71.5 & 71.9 \\
\hline
\end{tabular}

Note. Sev = severity; Inc = incidence; Whiteflies' nymphs were counted according to Abisgold and Fishpool (1990); AUDPC = area under disease progress curve; LSD $=$ least significant difference; $\mathrm{CV}=$ coefficient of variation.

\subsection{Yield and Yield Components}

Genotypes in the two sites were high significantly $(\mathrm{P}<0.001)$ different for storage root number, harvest index and fresh storage root yield. The interaction between genotypes in the two sites was highly significant $(\mathrm{P}<0.001)$ for storage roots number and fresh storage root yield. The number of roots per families ranged between 4.7 and 7.0 with an average mean of 5.4. Half sib progenies generated from MM96/4271 and Kaleso had high number of roots per plant compared to their respective parents. The highest mean number of roots was observed on progenies generated from family MM97/0293. The highest number of storage roots was recorded on genotypes, 
P2G8 and P4G1 at Kakamega and on genotypes, P5G10 and P5G11 at Alupe. Genotype, P2G8 from MM97/0293 had the highest number of storage roots but the lowest was by genotype P4G5 from MM96/0686. The number of storage roots among all the progenies ranged from 1.8 to 7.0.

Harvest index was observed to be high on progenies generated from parental lines Kaleso, MM96/0686 and MM96/4271. Parental lines, MM96/9308 and MM97/0293 had higher harvest index than their respective progenies. A comparison between the harvest index of half sib progenies and their respective parents, a number of progenies performed similarly as their parents. In both two sites, harvest index ranged between 0.3 and 0.7 with mean of 0.5 . The highest harvest index was observed on P5G8 and P5G11 generated from family MM96/9308.

The highest mean fresh storage root yield was recorded at Kakamega with mean of 18.2 t/ha compared to Alupe site with mean of $9.5 \mathrm{t} / \mathrm{ha}$. A range of half sib progenies from MM96/4271, Kaleso and MM96/0686 performed well in comparison to the yield recorded on their respective parents. Parental lines MM97/0293 and MM96/9308 had high storage roots yield compared to their progenies. Genotypes, P2G3, P4G1, P2G11, P2G9, P4G12, P2G2, P1G1 and P3G11 had the highest yield at Kakamega with an average of 30 to 50 t/ha. The lowest yield was observed on $41.5 \%$ of genotypes with an average of 0 to $15 \mathrm{t} / \mathrm{ha}$. The highest fresh storage root yield was recorded in Kakamega for genotypes, P2G3 and P4G1 with 50 t/ha. Genotype, P1G4 had the highest fresh storage root yield in Alupe and the lowest was P5G9 with $3.7 \mathrm{t} / \mathrm{ha}$. Across the two sites, the highest fresh storage root yields were recorded from P4G1 followed by P2G3 with mean fresh storage root yield of $31.6 \mathrm{t} / \mathrm{ha}$ and 30.0 $\mathrm{t} /$ ha, respectively while P3G6 and P5G9 recorded the lowest yield of $8.5 \mathrm{t} / \mathrm{ha}$.

The results showed no significant effect $(\mathrm{P}<0.05)$ of genotypes for dry matter content. A comparison between the dry matter content of half sib progenies and their respective parents shows that parents generally had higher dry matter content than their respective progenies though the difference was not significant at $5 \%$ significant level. Only parent MM96/0686 had a high number of progenies with high dry matter than that of their parent. The highest dry matter content was observed at Kakamega with a range from $24.6 \%$ to $48.3 \%$ compared to Alupe with a range of $16.3 \%$ to $40.7 \%$. Genotypes showing the highest dry matter content in Kakamega were, P3G2 and P4G4 with 48.3\% and 48.0\%, respectively while in Alupe the highest was genotype P1G5 with 40.7\%. In the two sites, there were no significant differences $(\mathrm{P}<0.05)$ among genotypes. Mean dry matter content across sites ranged between $29.1 \%$ and $41.7 \%$ with an average mean of $36.3 \%$.

\subsection{Cyanide Content in Cassava Roots}

Cyanide content varied significantly $(\mathrm{P}<0.001)$ among genotypes with a score ranging between 2.0 to 6.0 in both sites (Table 3). The highest scores of cyanide content were recorded on progenies from all the different families. Those genotypes are P1G3, P1G6, P1G11, P2G2, P2G3, P2G5, P2G10, P3G1, P4G8, P5G4, P5G5 and P5G12 with a range of 5.0 to 6.0 (Table 3). In term of location, the highest scores of cyanide content were recorded in Kakamega on genotypes P1G3, P1G6, P2G2, P2G3, P2G5, P3G1 and P5G5 generated from family MM96/4271, MM97/0293, Kaleso and MM96/9308. At Alupe site the highest scores were recorded on two genotypes P1G11 and P5G12 from MM96/4271 and MM96/9308 (Table 3). Cyanide content was also influenced by environmental conditions.

Table 3. Number of storage root, harvest index, fresh storage root yield, dry matter and cyanide content mean performance of cassava genotypes across sites during 2016-2017, season

\begin{tabular}{llllll}
\hline Genotypes & Storage root number & Harvest index & $\begin{array}{l}\text { Fresh storage root yield } \\
\left(\mathrm{t} \mathrm{ha}^{-1}\right)\end{array}$ & $\begin{array}{l}\text { Dry matter content } \\
(\%)\end{array}$ & Cyanide content \\
\hline P1G1 & 5.0 & 0.5 & 19.4 & 35.1 & 4.0 \\
P1G2 & 4.7 & 0.6 & 18.3 & 36.3 & 4.5 \\
P1G3 & 3.4 & 0.4 & 11.2 & 39.4 & 5.0 \\
P1G4 & 4.8 & 0.4 & 23.4 & 40.6 & 4.5 \\
P1G5 & 5.0 & 0.5 & 17.8 & 37.5 & 4.3 \\
P1G6 & 6.4 & 0.6 & 21.9 & 35.2 & 5.0 \\
P1G7 & 3.2 & 0.5 & 9.1 & 30.5 & 3.0 \\
P1G8 & 4.7 & 0.6 & 10.2 & 31.1 & 4.5 \\
P1G9 & 5.8 & 0.4 & 14.4 & 41.3 & 5.5 \\
P1G11 & 3.0 & 0.3 & 13.6 & 29.1 & 4.0 \\
P1G12 & 4.9 & 0.6 & 15.2 & 38.6 & 5.0 \\
P2G2 & 5.9 & 0.6 & 18.2 & 35.5 & \\
\hline
\end{tabular}




\begin{tabular}{|c|c|c|c|c|c|}
\hline P2G3 & 6.1 & 0.4 & 30.0 & 37.0 & 5.0 \\
\hline P2G4 & 5.5 & 0.6 & 18.8 & 35.8 & 4.5 \\
\hline P2G5 & 3.3 & 0.3 & 4.8 & 32.0 & 5.3 \\
\hline P2G6 & 3.1 & 0.4 & 15.2 & 39.0 & 4.0 \\
\hline $\mathrm{P} 2 \mathrm{G} 7$ & 4.0 & 0.6 & 11.3 & 32.5 & 3.5 \\
\hline P2G8 & 7.0 & 0.3 & 16.6 & 38.7 & 4.5 \\
\hline P2G9 & 5.8 & 0.3 & 19.0 & 34.2 & 4.3 \\
\hline P2G10 & 4.7 & 0.5 & 16.4 & 34.3 & 5.0 \\
\hline P2G11 & 6.2 & 0.5 & 23.6 & 38.2 & 4.0 \\
\hline P3G1 & 4.7 & 0.6 & 18.5 & 35.8 & 5.8 \\
\hline $\mathrm{P} 3 \mathrm{G} 2$ & 3.7 & 0.6 & 11.1 & 41.7 & 4.3 \\
\hline P3G3 & 3.4 & 0.5 & 14.1 & 35.7 & 4.0 \\
\hline P3G4 & 4.7 & 0.4 & 14.7 & 38.9 & 4.3 \\
\hline P3G5 & 6.6 & 0.6 & 12.5 & 40.2 & 3.0 \\
\hline P3G6 & 4.3 & 0.3 & 8.5 & 32.1 & 3.3 \\
\hline P3G7 & 6.7 & 0.4 & 19.7 & 36.8 & 3.5 \\
\hline P3G8 & 4.5 & 0.5 & 15.5 & 35.9 & 3.0 \\
\hline P3G9 & 3.2 & 0.5 & 11.9 & 36.2 & 4.0 \\
\hline P3G11 & 6.2 & 0.5 & 20.0 & 39.0 & 4.8 \\
\hline P4G1 & 6.7 & 0.5 & 31.6 & 36.2 & 4.0 \\
\hline P4G3 & 3.6 & 0.5 & 12.2 & 34.9 & 3.5 \\
\hline P4G4 & 3.4 & 0.4 & 9.3 & 40.3 & 4.8 \\
\hline P4G5 & 1.8 & 0.5 & 7.5 & 29.4 & 4.5 \\
\hline P4G6 & 4.9 & 0.6 & 15.4 & 36.4 & 2.0 \\
\hline P4G7 & 4.5 & 0.5 & 19.7 & 37.4 & 4.0 \\
\hline P4G8 & 4.7 & 0.6 & 19.9 & 35.3 & 5.3 \\
\hline P4G9 & 4.0 & 0.5 & 12.0 & 37.0 & 4.5 \\
\hline P4G12 & 6.5 & 0.5 & 19.6 & 38.8 & 2.0 \\
\hline P5G2 & 3.9 & 0.3 & 9.2 & 38.2 & 3.0 \\
\hline P5G3 & 4.1 & 0.6 & 13.8 & 33.9 & 4.0 \\
\hline P5G4 & 2.2 & 0.4 & 3.7 & 35.2 & 5.0 \\
\hline P5G5 & 5.1 & 0.4 & 12.8 & 36.2 & 5.5 \\
\hline P5G8 & 3.7 & 0.7 & 13.3 & 29.6 & 4.3 \\
\hline P5G9 & 4.3 & 0.3 & 8.5 & 38.2 & 4.0 \\
\hline P5G10 & 5.9 & 0.6 & 16.8 & 38.0 & 4.5 \\
\hline P5G11 & 5.6 & 0.7 & 15.9 & 36.7 & 4.0 \\
\hline P5G12 & 4.6 & 0.5 & 16.8 & 36.1 & 5.5 \\
\hline Kaleso & 4.4 & 0.4 & 13.4 & 37.5 & 4.3 \\
\hline MM96/0686 & 5.6 & 0.5 & 17.3 & 35.4 & 3.3 \\
\hline MM96/4271 & 4.4 & 0.5 & 15.2 & 39.5 & 3.5 \\
\hline MM96/9308 & 6.4 & 0.6 & 26.4 & 37.1 & 4.5 \\
\hline MM97/0293 & 6.2 & 0.6 & 25.8 & 38.7 & 4.3 \\
\hline Mean & 4.8 & 0.5 & 15.8 & 36.3 & 4.2 \\
\hline $\operatorname{LSD}(0.05)$ & 2.1 & 0.2 & 8.3 & 6.0 & 0.4 \\
\hline CV (\%) & 31.7 & 23.1 & 37.5 & 11.6 & 6.7 \\
\hline
\end{tabular}

Note. $\mathrm{LSD}=$ least significant difference; $\mathrm{CV}=$ coefficient of variation.

\subsection{Correlation Among Agronomic Traits, Disease Expression and Yield}

Correlations coefficients from combined data of the two locations were done on fifty four genotypes. Significant correlation was observed among plant height, levels of cassava mosaic disease, yield and cyanide content. Taller genotypes were observed to have high yield and high number of storage roots, but lower harvest index. High yielding genotypes presented high number of storage roots per plant, high dry matter and they were affected $(\mathrm{P}<$ 0.05 ) by cassava mosaic disease. Genotypes with higher storage root number had higher dry matter. 
Table 4. Phenotypic correlation coefficients between agronomic, disease intensity and yield traits evaluated on fifty four genotypes at Kakamega and Alupe

\begin{tabular}{lllllllll}
\hline & $\begin{array}{l}\text { Plant } \\
\text { height }\end{array}$ & $\begin{array}{l}\text { Fresh root } \\
\text { yield }\end{array}$ & $\begin{array}{l}\text { Harvest } \\
\text { index }\end{array}$ & $\begin{array}{l}\text { Number } \\
\text { of roots }\end{array}$ & $\begin{array}{l}\text { Dry matter } \\
\text { content }\end{array}$ & $\begin{array}{l}\text { Cyanide } \\
\text { content }\end{array}$ & $\begin{array}{l}\text { CMD } \\
\text { severity }\end{array}$ & $\begin{array}{l}\text { CMD } \\
\text { incidence }\end{array}$ \\
\hline Plant height & - & & & & & & \\
Fresh root yield & $0.4051^{* *}$ & - & & & & & \\
Harvest index & $-0.2293^{* *}$ & $0.1657^{*}$ & - & & & & \\
Number of roots & $0.3400^{* *}$ & $0.7435^{* *}$ & 0.1132 & - & & & \\
Dry matter content & $0.2163^{* *}$ & $0.3146^{* *}$ & 0.0113 & $0.3155^{* *}$ & - & & - \\
Cyanide content & -0.1264 & $0.1441^{*}$ & 0.0802 & 0.0587 & -0.0352 & - & -0.0868 & - \\
CMD severity & -0.0668 & $-0.2306^{* *}$ & -0.0873 & $-0.1618^{*}$ & -0.0413 & $0.1854^{* *}$ & - \\
CMD incidence & -0.0721 & -0.0847 & -0.0748 & $-0.1767^{*}$ & -0.1065 & 0.1072 & 0.185 \\
\hline
\end{tabular}

Note. ${ }^{*}, * *=$ Significant difference at $\mathrm{P}<0.05$ and $0.01 ;$ AUDPC $=$ Area under the disease progress curve.

\section{Discussion}

\subsection{Plant Height}

Variability was observed among genotypes for plant height indicating that it was dependent on genotypes. Genotype and location interaction varied significantly for this trait. The tallest genotypes were observed in one site compared to another, respectively. The genotypes were generally tall in Kakamega with mean height of $155.6 \mathrm{~cm}$ compared to $112.9 \mathrm{~cm}$ in Alupe. According to the effect of environment, Laban et al. (2013) reported similar results where genotypes and locations significantly varied among themselves for plant height in three locations in Uganda.

Assessment of the growing conditions such as rainfall, temperature, solar radiation showed that, the climatic conditions were ideal to support growth of the plant (Yihong et al., 2009). Previous studies by Laban et al. (2013) reported similar results of stunted growth in cassava as result of water stress. Aina et al. (2007) using Nigerian cassava germplasm reported a decline of $41 \%$ while Bergantin et al. (2004) using a range of cassava genotypes in the Philippines reported a decline of $62.05 \%$.

\subsection{Reaction to Cassava Mosaic Disease}

The development of cassava mosaic disease was variable in the two sites, and resulted in different levels of severity scores. Though there were significant differences between parents and their respective progenies in their reaction to cassava mosaic disease severity, there were a varying number of symptomless clones generated from different cassava families involved. Of all the families, Kaleso had the highest percentage of clones that remained symptomless followed by MM96/4271 respectively. The lowest percentage of symptomless clones was recorded in family MM97/0293, MM96/0686 and MM96/9308. Alupe site was observed to have high number of genotypes showing susceptibility compared to Kakamega, indicating the effect of the environment on the evaluated genotypes.

This observation concurs with that of Akainwale et al. (2011) where the significant $(\mathrm{P}<0.001)$ differences between the materials used and seasons influenced the response of the genotypes to cassava mosaic disease infection. The observation agrees also with the study by Chikoti et al. (2016) where, none of the genotypes showed resistance to cassava mosaic disease; however $56.3 \%$ of the genotypes were more tolerant to the disease. This might be due to the influence of the environment on the cassava mosaic virus and $B$. tabaci and growth activities of the plants (Fargette et al., 1993). This might also imply that virus replication and symptom expression are controlled by distinct genes in cassava as alluded to by Kaweesi et al. (2014) when working with cassava brown streak virus and Uganda cassava brown streak virus.

According to Kiweesi et al. (2014), and Maruthi et al. (2014), plants with low virus quantities and low symptom severity expression are regarded as resistant or tolerant. Cassava mosaic disease development is affected by environmental conditions and may vary depending on location of the field and year of cultivation (Sing'ombe et al., 2015). Many cassava mosaic disease-resistant varieties can be infected by cassava mosaic disease but express mild symptoms that have little significant impact on yield (Tembo et al., 2017).

\subsection{Population and Incidence of White Fly Nymphs}

The study showed variability on the number of whitefly nymphs among different genotypes generated from different parents used, and the locations. Among progenies, the highest number of white fly nymphs was observed 
on P3G8 and the lowest on P1G7. Progenies from parental genotype were found to have high number of whiteflies nymphs, while having the lowest severity score and symptomless plants, indicating that those genotypes were the most likely by the whiteflies, therefore showed a high level of resistant to white flies' attack. According to the observation during data collection in the trials, whitefly nymphs were observed to be predominantly high during the dry season compared to rain season in both two locations, indicating that their presence is mainly influenced by climatic condition.

Result agrees with that of Otim et al. (2006) where higher numbers of whitefly nymphs were found on resistant varieties when compared to susceptible varieties of cassava. Ekbom and Xu (1990) noted that the distribution of B. tabaci on plants was far from random, since the insects tend to select both particular plants and parts of the plant. This is consistent with the observations made by Legg et al. (2003), and is attributed to the whitefly preference for the resistant variety.

Seasonal changes in diversity and density of pests in tropical regions have been related in several studies and have been attributed to temporal variation in local environmental factors such as temperature, rainfall and relative humidity (Klein et al., 2002; Philpott et al., 2006; Teodoro et al., 2008).

\subsection{Yield and Yield Components}

Significant variations $(\mathrm{P}<0.001)$ were observed for fresh storage root yield, storage root number and harvest index indicating wide genetic differences. Harvest index varied significantly with most of the genotypes having values ranging between $30 \%$ and $70 \%$. Thirty two half-sib families plus their four parents had harvest index ranging from $50 \%$ to $70 \%$, which was very high according to the optimum values of $50 \%$ to $60 \%$ for cassava (Iglesias et al., 1994). A high number of half sib progenies from MM96/4271, Kaleso and MM96/0686 performed very well in comparison with the yield recorded on their respective parents. Low yields were observed in Alupe compared to Kakamega. It has been observed that the rainfall was high at Kakamega than that at Alupe (Appendix 1). This could have influenced the relatively better performance of genotypes in root yield in Kakamega than Alupe. The amount of dry matter value obtained across site ranged between $29.1 \%$ and $41.7 \%$. A comparison between the dry matter content of half sib progenies and their respective parents' shows that parents equalized with their respective progenies as the difference was not significant at $5 \%$ significant level.

The result obtained in the study for harvest index was high compared to those reported by Chikoti et al. (2016) where they got values ranging between $44 \%$ and $55 \%$. Harvest index was a highly heritable trait and less affected by the environment (Kawano et al., 1998). The report agrees with Chikoti (2016) when reaction of the genotypes to fresh storage roots yield differed significantly, ranging from $0.24 \mathrm{~kg} / \mathrm{plant}$ to $0.87 \mathrm{~kg} / \mathrm{plant}$. This may be due to varietal and climatic superiority especially in their ability to utilize resources more efficiently through appropriate partitioning of assimilates (Mandal, 2006). The results on dry matter content in the study agree with that of Gifty (2015) where the amount of dry matter produced ranged from 30\% in Debor and $40 \%$ in Agbelifia respectively. Teye et al. (2011) also got similar result, as observed by Gifty (2015), when the dry matter values obtained ranged between $31.45 \%$ and $40.74 \%$. Root dry matter content ranging between $23-43 \%$ has been reported by other workers (Okechukwu \& Dixon, 2009).

Though cassava crop is tolerant to drought, at some stage in preliminary growth stages moisture content in the soil is essential. Kiweesi (2014) reported that low yield could be due to yield cost on the plant due to resistance to disease when Namikonga presented low yield among others. Cassava grows well in less fertile soil but a considerable amount of nitrogen is required (Howeler, 2002). The critical period for water deficient in cassava is 1-5 MAP, which coincides with the stages of root initiation and tuberisation (Aina et al., 2007). Higher climatic conditions including temperature moisture and humidity favoured the varieties during the vegetative stages but during the reproductive stages, overall yield was affected through strong negative correlation between resource-use and yield components (Gifty, 2015).

\subsection{Cyanide Content in Cassava Roots}

The result yielded concentrations of cyanide ranging from $20 \mathrm{mg} / \mathrm{kg}$ to $60 \mathrm{mg} / \mathrm{kg}$ of fresh tubers. Progenies from all the five families showed a high concentration of cyanide content. The analysis revealed higher levels of cyanide above the recommended safe limit of $10 \mathrm{mg} / \mathrm{kg}$ (Tchacondo et al., 2011). Bitter cassava recorded high concentration of cyanide compared to the sweet cassava. Similar result has been obtained by Ezeigbo et al. (2015) when cassava cultivars 30211, 30572, 0581 and 8083 had higher concentration of cyanide than the cultivar 0505 . Wheatley et al. (1993) obtained similar results, although the present survey recorded lower concentrations of cyanide in all the species investigated. According to literature, time of harvest influences cyanide content of fresh cassava. Harvest conducted during the rainy season and in the afternoon would significantly reduce the rate of cyanide in the cassava products (Silvestre et al., 1983). 


\subsection{Correlation Among Agronomic Traits, Disease Expression and Yield}

The correlation between storage root yield with number of storage roots, harvest index and dry matter content were positive and highly significant. Egesi et al. (2007) reported similar results for the correlations of fresh root yield with number of roots plot $^{-1}$, and top biomass and contrasting results for the correlation between harvest index and fresh foliage mass. The results of this study indicated that fresh storage root yield, harvest index, storage root number and dry matter content can be selected simultaneously as they are positively and significantly correlated. Negative and significant correlations were observed for fresh storage root yield and storage root number with cassava mosaic disease, respectively. Okechukwu and Dixon (2009) reported negative correlation coefficients between cassava mosaic disease and yield. On the contrary, studies by Ssemakula and Dixon (2007) reported significant positive correlation between cassava mosaic disease and yield. In cases where cassava mosaic disease presented a weak and positive correlation with a trait, it suggested that cassava mosaic disease had no effect on the particular trait (Chikoti et al., 2016).

\section{Conclusion}

The study has identified high yielding half-sib progenies from Kenya that are resistant to cassava mosaic disease and other traits of agronomic importance such as yield, yield components and root quality, indicating that these materials could be used in the future in breeding programmes to generate cassava varieties that combine all the desired traits. Evaluation of new cassava varieties under local disease conditions would most likely improve the productivity of cassava through selection of resistant clones.

\section{Acknowledgements}

This publication was made possible through support provided by Alliance for Green Revolution in Africa (AGRA) Grant No. 2015 PASS 011. The opinions expressed herein are those of the author (s) and do not necessarily reflect the views of AGRA.

\section{References}

Abisgold, J. D., \& Fishpool, L. D. C. (1990). A method for estimating population sizes of whitefly nymphs (Bemisia tabaci Genn.) on cassava. Tropical Pest Management, 36(3), 287-292. https://doi.org/10.1080/096 70879009371490

Aina, O. O., Dixon, A. G. O., \& Akinrinde, E. A. (2007). Effect of soil moisture stress on growth and yield of cassava in Nigeria. Pakistan Journal of Biological Science, 10(18), 3085-3090. https://doi.org/10.3923/ pjbs.2007.3085.3090

Akainwale, M. G., Akinyele, B. O., Odiyi, A. C., \& Dixon, A. G. O. (2011). Genotype × environment interaction and yield performance of 43 improved cassava (Manihot esculenta Crantz) genotypes at three agro-climatic zones in Nigeria. British Biotechnology Journal, 1(3), 68-84. https://doi.org/10.9734/BBJ/2011/475

Aloyce, R. C., Tairo, F., Sseruwagi, P., Rey, M. E. C., \& Ndunguru, J. (2013). A single-tube duplex and multiplex PCR for simultaneous detection of four cassava mosaic begomovirus species in cassava plants. Journal of virological Methods, 189(1), 148-156. https://doi.org/10.1016/j.jviromet.2012.10.007

Benesi, I. R. M. (2005). Characterisation of Malawian cassava germplasm for diversity, starch extraction and its native and modified properties (PhD thesis, University of the Free State, South Africa).

Bergantin, V. R., Yamauchi, A., Pardales, J. R., \& Bolatete, D. M. Jr. (2004). Screening cassava genotypes for resistance to water deficit during crop establishment. Philippine Journal of Crop Science, 29(1), 29-39.

Bhat, R., Alias, A. K., \& Paliyath, G. (2012). Progress in food preservation. John Wiley and Sons. https://doi.org/10.1002/9781119962045

Bigirimana, S., Barumbanze, P., Obonyo, R., \& Legg, J. P. (2004). First evidence for the spread of East African cassava mosaic virus-Uganda (EACMV-UG) and the pandemic of severe cassava mosaic disease to Burundi. Plant Pathology, 53(2), 231-231. https://doi.org/10.1111/j.0032-0862.2004.00971.x

Ceballos, H., Iglesias, C. A., Pérez, J. C., \& Dixon, A. G. (2004). Cassava breeding: Opportunities and challenges. Plant Molecular Biology, 56(4), 503-516. https://doi.org/10.1007/s11103-004-5010-5

Chikoti, P. C., Shanahan, P., \& Melis, R. (2016). Evaluation of cassava genotypes for resistance to cassava mosaic disease and agronomic traits. American Journal of Plant Sciences, 7(07), 1122-1128. https://doi.org/ 10.4236/ajps.2016.77107

Cossa, N. S. (2011). Epidemiology of cassava mosaic disease in Mozambique (MSc thesis, University of Witwatersrand, Johannesburg, South Africa). 
DeVries, J., \& Toenniessen, G. (2001). Securing the harvest: Biotechnology, breeding and seed systems for African crops. CABI Publishing, New York, USA. https://doi.org/10.1079/9780851995649.0000

Egesi, C. N., Ilona, P., Ogbe, F. O., Akoroda, M., \& Dixon, A. (2007). Genetic variation and genotype $\times$ environment interaction for yield and other agronomic traits in cassava in Nigeria. Agronomy Journal, 99(4), 1137-1142. https://doi.org/10.2134/agronj2006.0291

Ekbom, B. S., \& Xu, R. (1990). Sampling and Spatial Patterns of Whiteflies. In D. Gerling (Ed.), Whiteflies: Their Bionomics, Pest Status and Management (pp. 107-121). Intercept, Hants, United Kingdom.

Ezeigbo, O. R., Ukpabi, C. F., Ike-Amadi, C. A., \& Ekaiko, M. U. (2015). Determination of Starch and Cyanide Contents of different Species of Fresh Cassava Tuber in Abia state, Nigeria. British Biotechnology Journal, 6(1), 10-15. https://doi.org/10.9734/BBJ/2015/15297

Fargette, D., \& Vie, K. (1995). Simulation of the effects of host resistance, reversion and cutting selection on incidence of cassava mosaic virus and yield losses in cassava. Journal of Phytopathology, 85(3), $370-375$. https://doi.org/10.1094/Phyto-85-370

Fargette, D., Jeger, M., Fauquet, C., \& Fishpool, L. D. C. (1993). Analysis of temporal disease progress of African cassava mosaic virus. Ecology and Epidemiology, 84(1), 91-98.

Fukuda, W. M. G., Guevara, C. L., Kawuki, R., \& Ferguson, M. E. (2010). Selected morphological and agronomic descriptors for the characterization of cassava.

Gifty, B. G. (2015). Evaluation of growth, yield and root quality of four (4) cassava (manihotesculentacrantz) varieties in the semi-deciduous zone of Ghana (MSc. Thesis, Faculty of Agriculture, Kwame Nkrumah University of Science and Technology, Kumasi, Ghana).

Gondwe, F. M. T., Mahungu, N. M., Hillocks, R. J., Raya, M. D., Moyo, C C., Soko, M. M., ... Benesi, I. R. M. (2003). Economic losses experienced by small-scale farmers in Malawi due to cassava brown streak virus. In J. P. Legg, \& R. J. Hillocks (Eds.), Cassava Brown Streak Disease: Past, Present and Future (pp. 28-35). Proceedings of an International Workshop, Mombasa, Kenya, October 20-30, 2002. National Resources International Limited, Aylesford, the United Kingdom.

Hillocks, R. J., \& Jennings, D. L. (2003). Cassava brown streak disease: A review of present knowledge and research needs. International Journal of Pest Management, 49(3), 225-234. https://doi.org/10.1080/096708 7031000101061

Howeler, R. H. (2002). Cassava mineral nutrition and fertilization. Cassava: Biology, production and utilization (pp. 115-147).

IFAD (International Fund for Agricultural Development) and FAO (Food and Agriculture Organization of the United Nations). (2000). The world cassava economy: Facts and outlook. Rome.

Iglesias, C. A., Calle, F., Hershey, C., Jaramillo, G., \& Mesa, E. (1994). Sensitivity of Cassava (Manihot esculenta Crantz) Clones to Environmental Changes. Field Crop Research, 36(3), 213-220. https://doi.org/ 10.1016/0378-4290(94)90113-9

IITA (International Institute of Tropical Agriculture). (1990). Cassava in Tropical Africa (p. 108). IITA, Ibadan, Nigeria.

Jaetzold, R., \& Schmidt, H. (1983). Farm management of Kenya. National conditions and farm management information (Volume 11 C, pp. 325-366). Farm Management Branch, Ministry of Agriculture, Nairobi, Kenya.

Kawano, K., Narintaraporn, K., Narintaraporn, P., Sarakarn, S., Limsila, A., Limsila, J., \& Watananonta, W. (1998). Yield improvement in a multistage breeding program for cassava. Crop Science, 38(2), 325-332. https://doi.org/10.2135/cropsci1998.0011183X003800020007x

Kiweesi, T., Kawuki, R., Kyaligonza, V., Baguma, Y., Tusiime, G., \& Ferguson, M. (2014). Field evaluation of selected cassava genotypes for cassava brown streak disease based on symptom expression and virus load. Virology Journal, 11(1), 216. https://doi.org/10.1186/s12985-014-0216-X

Klein, A. M., Stefan-Dewenter, I., \& Buchori, D. (2002). Effects of land-use intensity in tropical agroforestry systems on coffee flower visiting and trap-nesting bees and wasps. Conservation Biology, 16(4), 1003-1014. https://doi.org/10.1046/j.1523-1739.2002.00499.x 
Laban, T. F., Baguma, Y., Kizito, E. B., \& Osiru, D. (2013). Evaluation of Ugandan cassava germplasm for drought tolerance. International Journal of Agriculture and Crop Sciences, 5(3), 212-226.

Legg, J. P., Abele, S., Obiero, H., Jeremiah, S., Bigirimana, S., \& Ntawuruhunga, P. (2005). The Cassava mosaic virus disease pandemic and its impact on people's livelihoods in East and Central Africa. Phytopathology, 95(6), 129-130.

Legg, J. P., Mallowa, S., \& Sseruwagi, P. (2003). First report of physical damage to cassava caused by the whitefly, Bemisiatabaci (Gennadius) (Hemiptera: Sternorrhyncha: Aleyrodidae). Book of Abstracts, 3rd International Bemisia Workshop. Barcelona, 17/20 March, 2003.

Legg, J. P., OkaoOkuja, G., Mayala, R., \& Muhinyuza, J. B. (2001). Spread into Rwanda of the severe cassava mosaic virus disease pandemic and the associated Uganda variant of East African cassava mosaic virus (EACMV-UG). Plant Pathology, 50(6), 796-796. https://doi.org/10.1046/j.1365-3059.2001.00619.x

Mandal, R. C. (2006). Tropical root and tuber crops. Cassava (Tapioca), sweet potato, aroids, yams, yam bean, coleus. AGROBIOS, India.

Maruthi, M. N., Bouvaine, S., Tufan, H. A., Mohammed, I. U., \& Hillocks, R. J. (2014). Transcriptional response of virus-infected cassava and identification of putative sources of resistance for cassava brown streak disease. PloS One, 9(5), e96642. https://doi.org/10.1371/journal.pone.0096642

Monde, G., Walangululu, J., Winter, S., \& Bragard, C. (2010). Dual infection by cassava begomoviruses in two leguminous species (Fabaceae) in Yangambi, Northeastern Democratic Republic of Congo. Archive Virology, 155(11), 1865-69. https://doi.org/10.1007/s00705-010-0772-3

Musopole, H. T. (2016). Quantification of cassava mosaic geminiviruses and cassava brown streak viruses (MSc. thesis, Faculty of Natural and Agricultural Sciences at the University of the Free State, South Africa).

Okechukwu, U. R., \& Dixon, A. G. O. (2009). Performance of improved cassava genotypes for early bulking, disease resistance and culinary qualities in an inland valley ecosystem. Agronomy Journal, 101(5), 1258-1265. https://doi.org/10.2134/agronj2008.0077

Okogbenin, E., Ekanayake, I. J., \& Porto, M. C. M. (2003). Genotypic variability in adaptation responses of selected clones of cassava to drought stress in the Sudan savanna zone of Nigeria. Journal of Agronomy Crop Science, 189(6), 376-389. https://doi.org/10.1046/j.1439-037X.2003.00050.x

Otim, M., Legg, J. P., Kyamanywa, S., Polaszek, A., \& Gerling, D. (2006). Population dynamics of Bemisiatabaci (Homoptera: Aleyrodidae) parasitoids on cassava mosaic Disease/Resistant and susceptible varieties. Biocontrol Science and Technology, 16(2), 205-214. https://doi.org/10.1080/09583150500335558

Pennisi, E. (2010). Armed and dangerous. Science, 327, 804-805. https://doi.org/10.1126/science.327.5967.804

Philpott, S., Perfecto, I., \& Vandermeer, J. (2006). Effects of management intensity and season on arboreal ant diversity and abundance in coffee agroecosystems. Biodiversity and Conservation, 15, 139-155. https://doi.org/10.1007/s10531-004-4247-2

Sanginga, N., \& Mbabu, A. (2015). Root and tuber crops (Cassava, Yam, Potato and Sweet potato). Proceedings of The Action Plan for African Agricultural Transformation Conference, Dakar, Senegal (pp. 21-23).

SAS. (1999). SAS/STAT User's Guide, Version 8. SAS Institute Incorporated.

Shaner, G., \& Finney, R. E. (1977). The effect of nitrogen fertilization on the expression of slow-mildewing resistance in Knox wheat. Phytopathology, 67(8), 1051-1056. https://doi.org/10.1094/Phyto-67-1051

Silvestre, P., \& Arraudeau, M. (1983). Le manioc. Techniques Agricoles et Production Tropicales (Vol. 32, p. 262). Maisonneuve et Larose, Paris, France.

Sing'ombe, G., Ateka, E., Miano, D., Githiri, S., Munga, T., \& Mwaura, S. (2015). Assessment of the responses of cassava (Manihotesculenta) breeder's germplasm to cassava mosaic virus (CMD) infection in Kenya. International Journal of Agronomy and Agricultural Research, 6(4), 120-129.

Ssemakula, G., \& Dixon, A. (2007). Genotype x environment interaction, stability and agronomic performance of carotenoid-rich cassava clones. Scientific Research and Essay, 2, 390-399.

Sseruwagi, P., Rey, M. E. C., Brown, J. K., \& Legg, J. P. (2004a). The cassava mosaic geminiviruses occurring in Uganda following the 1990s epidemic of the severe cassava mosaic disease. Annals of Applied Biology, 145(1), 113-121. https://doi.org/10.1111/j.1744-7348.2004.tb00366.x 
Tchacondo, T., Karou, S. D., Osseyi, E., Agban, A., Bawa, L. M., Atcha, A. R., ... De Souza, C. (2011). Effect of harvest and cook processing on cyanide content of cassava-based dough consumed in Lome, Togo. Advanced Journal of Food Science and Technology, 3(5), 399-403.

Tembo, M., Mataa, M., Legg, J., Chikoti, P. C., \& Ntawuruhunga, P. (2017). Cassava mosaic disease: Incidence and yield performance of cassava cultivars in Zambia. Journal of Plant Pathology, 99(3), 1-28.

Teodoro, A. V., Klein, A. M., \& Tscharntke, T. (2008). Environmentally mediated coffee pest densities in relation to agroforestry management, using hierarchical partitioning analyses. Agriculture, Ecosystems and Environment, 125(1), 120-126. https://doi.org/10.1016/j.agee.2007.12.004

Teye, E., Asare, A. P., Amoah, R. S., \& Tetteh, J. P. (2011). Determination of the dry matter content of cassava (Manihot esculenta, Crantz) tubers using specific gravity method. Journal of Agriculture and Biological Science, 11(6), 23-28.

Thresh, J. M., Otim-Nape, G. W., Legg, J. P., \& Fargette, D. (1997). African cassava mosaic virus disease: The magnitude of the problem. African Journal Root and Tuber Crops, 2(1/2), 11-17.

Virk, D. S., \& Witcombe, J. R. (2007). Trade-offs between on-farm varietal diversity and highly client-oriented breeding: A case study of upland rice in India. Genetic Resources Crop Evolution, 54(4), 823-835. https://doi.org/10.1007/s10722-006-9158-5

Were, H. K., Winter, S., \& Maiss, E. (2004). Variations and taxonomic status of begomoviruses causing severe epidemics of cassava mosaic disease in Kenya, Uganda, and Democratic Republic of the Congo. Journal of General Plant Pathology, 70(4), 243-248. https://doi.org/10.1007/s10327-003-0119-y

Wheatley, C. C., Orrego, J. I., Sanchez, T., \& Granados, E. (1993). Quality evaluation of cassava core collection at CIAT. In W. M. Rica, \& A. M. Thro (Eds.), Proceedings of the First International Scientific Meeting of the Cassava Biotechnology (pp. 255-257). New York, CCIAT, Crtagena, Columbia.

Witcombe, J. R., Joshi, A., Joshi, K. D., \& Sthapit, B. R. (1996). Farmer participatory crop improvement: I. Varietal selection and breeding methods and their impact on biodiversity. Experimental Agriculture, 32(4), 445-460. https://doi.org/10.1017/S0014479700001526

Yihong, K. (2009). Climate change impacts on crop yield, crop water productivity and food security-A review. Progress in Natural Science, 19(12), 1665-1674. https://doi.org/10.1016/j.pnsc.2009.08.001

Zhang, P., Vanderschuren, H., Futterer, J., \& Gruissem, W. (2005). Resistance to cassava mosaic disease in transgenic cassava expressing antisense RNAs targeting virus replication genes. Plant Biotechnology Journal, 3(4), 385-397. https://doi.org/10.1111/j.1467-7652.2005.00132.x

\section{Copyrights}

Copyright for this article is retained by the author(s), with first publication rights granted to the journal.

This is an open-access article distributed under the terms and conditions of the Creative Commons Attribution license (http://creativecommons.org/licenses/by/4.0/). 